Kusumiyati $\cdot$ W. Sutari $\cdot$ N. Raniska

\title{
Respons pertumbuhan, hasil, dan kualitas hasil buncis tegak terhadap pemberian berbagai dosis kompos dan interval panen pada Inceptisols Jatinangor
}

\section{Growth, yield, and quality response of snap beans to the doses of compost and harvest interval on Inceptisols Jatinangor}

Diterima : 15 Juli 2016/Disetujui : 10 Agustus 2016 / Dipublikasikan : 30 Agustus 2016

CDepartment of Crop Science, Padjadjaran University

\begin{abstract}
The decrease of bean production causes unfulfilled demand. That decrease caused by several things, such as suboptimal land conditions and poor quality of beans. This research was aimed to find out the doses of compost and harvest interval that gives the best effect on growth, yield, and quality of snap beans on Inceptisols Jatinangor. The experiment was conducted at the experimental field Faculty of Agriculture Universitas Padjadjaran, Ciparanje Kecamatan Jatinangor, Kabupaten Sumedang with altitude $\pm 750 \mathrm{~m}$ above sea level, from February-April 2016. According to the classification of Oldeman the type of rainfall is type C3. The experiment was arranged in the Randomized Block Design, consisting of 12 combinations of treatment and replicated 3 times. The combinations were consisted of 4 doses of compost; $0 \mathrm{~kg}, 2.5 \mathrm{~kg}, 5 \mathrm{~kg}$, and $7.5 \mathrm{~kg}$ per plot and harvest interval every 1 day, 2 days, and 3 days. The addition of $0 \mathrm{~kg}$ compost with 1, 2, and 3 days of harvest interval, and also addition of $5 \mathrm{~kg}$ and $7.5 \mathrm{~kg}$ compost with 1 day of harvest interval gave the highest percentage of marketable beans. The best doses and harvest interval refers to the result, that is $100 \%$ compost and 1 days harvest interval.
\end{abstract}

Keywords: Snap beans · Inceptisols · Harvest interval . Compost.

Sari. Produksi buncis yang menurun mengakibatkan tidak terpenuhinya permintaan. Penurunan tersebut disebabkan oleh beberapa hal, seperti kondisi lahan suboptimal dan kualitas hasil yang kurang baik. Penelitian ini bertujuan untuk

\footnotetext{
Dikomunikasikan oleh Yudithia Maxiselly

Kusumiyati $^{1} \cdot$ W. Sutari ${ }^{1} \cdot$ N. Raniska ${ }^{2}$

${ }^{1}$ Staff pengajar program studi Agroteknologi Fakultas Pertanian Unpad

${ }^{2}$ Alumni program studi Agroteknologi Fakultas Pertanian Unpad
}

mengetahui dosis kompos dan interval panen yang memberikan pengaruh terbaik terhadap pertumbuhan, hasil, dan kualitas hasil buncis tegak pada Inceptisols Jatinangor. Percobaan dilaksanakan di kebun percobaan Fakultas Pertanian Universitas Padjadjaran, di Ciparanje Kecamatan Jatinangor, Kabupaten Sumedang pada ketinggian \pm 750 meter di atas permukaan laut ( $\mathrm{m} \mathrm{dpl}$ ), selama bulan Februari - April 2016. Tipe iklim kawasan Jatinangor berdasarkan Oldeman adalah C3. Rancangan percobaan yang digunakan adalah Rancangan Acak Kelompok (RAK), dengan 12 kombinasi perlakuan yang diulang sebanyak 3 kali. Kombinasi perlakuan terdiri dari 4 dosis kompos sebanyak $0 \mathrm{~kg}, 2.5 \mathrm{~kg}, 5 \mathrm{~kg}$, dan $7.5 \mathrm{~kg}$ per petak serta interval panen setiap 1 hari, 2 hari, dan 3 hari sekali. Hasil penelitian menunjukkan perbedaan pada persentase polong layak pasar dan tidak layak pasar, dimana pemberian kompos $0 \mathrm{~kg}$ dengan interval panen 1, 2, dan 3 hari sekali, serta pemberian kompos $5 \mathrm{~kg}$ dan $7.5 \mathrm{~kg}$ dengan interval panen 1 hari menghasilkan polong dengan persentase layak pasar tertinggi. Kombinasi terbaik adalah dosis kompos dengan dosis $100 \%$ dan interval panen 1 hari.

Kata kunci: Buncis tegak · Inceptisols · Interval panen $\cdot$ Kompos.

\section{Pendahuluan}

Di era modern saat ini, tren hidup sehat sedang diminati oleh banyak masyarakat, terutama dari kalangan menengah ke atas. Tak heran apabila produk hortikultura sangat digemari masyarakat karena memiliki kandungan vitamin tinggi. Buncis menjadi salah satu produk hortikultura yang diminati masyarakat. Buncis (Phaseolus vulgaris L) merupakan tanaman yang cocok dibudidayakan di dataran medium (buncis tegak) maupun tinggi (buncis rambat). 
Produksi tanaman buncis cenderung mengalami penurunan setiap tahunnya selama tahun 2009-2013. Pada tahun 2009, produksi buncis nasional mencapai angka 290.993 ton dan naik menjadi 336.494 ton pada tahun 2010. Berturut - turut pada tahun 2011, 2012, dan 2013 produksi buncis mengalami penurunan menjadi 334.659 ton, 322.097 ton, dan 312.464 ton (Direktorat Jenderal Hortikultura, 2014). Data yang dihimpun oleh Badan Pusat Statistik (2015) pada tahun 2014 menunjukkan bahwa Indonesia masih melakukan impor buncis. Total buncis yang diimpor pada tahun 2014 adalah sebanyak 6,94 ton.

Buncis menjadi salah satu komoditas penting di dunia, namun cekaman biotik dan abiotik adalah salah satu faktor pembatas yang mengurangi produksi buncis. FAO melaporkan bahwa produksi buncis dunia mengalami penurunan, sehingga permintaan terancam tidak dapat dipenuhi (Porch et al., 2013). Salah satu penyebab dari menurunnya produksi buncis adalah keterbatasan lahan yang kondisinya tidak sesuai dengan lingkungan tumbuh buncis. Di Indonesia, masih banyak lahan yang tergolong suboptimal, sedangkan buncis menghendaki media tanam dengan drainase yang baik.

Lahan suboptimal adalah lahan yang secara alami memiliki satu atau beberapa kendala pengelolaan, namun dapat digunakan untuk kegiatan pertanian dengan usaha yang lebih ekstra (Rajiman, 2015). Inceptisols adalah salah satu ordo tanah yang banyak tersebar di Indonesia dan memiliki kesuburan yang tergolong rendah. Di daerah Jatinangor, Inceptisols sering digunakan sebagai media untuk bercocok tanam, namun kendala seperti tanah yang masam, kandungan unsur hara yang rendah dan tekstur liat cukup menghambat kegiatan budidaya yang dilaksanakan.

Murtilaksono dan Anwar menyebutkan bahwa terdapat beberapa usaha yang dapat dilakukan untuk menanggulangi kondisi lahan tersebut, yaitu dengan pemberian pembenah tanah dan pemupukan, penataan pola tanam, serta konservasi tanah dan air. Pemupukan menjadi salah satu alternatif untuk memperbaiki sifat Inceptisols. Menurut Sarief (1985), pemupukan adalah suatu usaha untuk meningkatkan persediaan unsur hara yang dibutuhkan oleh tanaman, sehingga produksi dan mutu hasil tanaman pun akan meningkat.

Terdapat 2 jenis pupuk yang dapat digunakan, yaitu pupuk organik dan pupuk anorganik. Pupuk organik memiliki banyak keunggulan bila dibandingkan dengan pupuk anorganik. Alison (1973) menyatakan bahwa dengan penambahan pupuk organik di tanah, maka lingkungan tumbuh tanaman menjadi lebih baik melalui perbaikan agregat, air, aerasi, suhu, dan penetrasi akar. Melalui perbaikan tersebut maka tata air dan udara tanah dapat terjaga dengan seimbang (Sarief, 1985).

Salah satu jenis pupuk organik yang umum digunakan adalah kompos. Kompos berasal dari campuran sisa tanaman dan kotoran hewan yang telah mengalami proses dekomposisi secara sempurna. Kompos dengan campuran kotoran sapi dinilai cukup baik karena unsur hara yang terkandung di dalam kompos kotoran sapi relatif lebih baik, selain itu pupuk kompos kotoran sapi juga memiliki kemampuan yang baik untuk memerbaiki sifat tanah dan mensuplai unsur N, P, dan K (Pujisiswanto dan Pangaribuan, 2008).

Penambahan bahan organik tanah dapat berperan terhadap pertumbuhan buncis. Buncis umumnya dipanen saat muda dengan interval waktu 2-3 hari, atau setelah polongnya memenuhi kriteria panen. Hal ini dikarenakan tingkat kematangan polong buncis yang tidak serempak. Perbedaan interval waktu panen dapat menyebabkan perbedaan kualitas polong buncis yang dipanen pada interval waktu 2 dan 3 hari. Polong yang dipanen pada interval waktu 2 hari cenderung memiliki kualitas yang lebih memenuhi standar, apabila dibandingkan dengan polong yang dipanen pada interval waktu 3 hari, karena semakin lama interval panen maka semakin tua polong buncis. Kandungan bahan organik dan suplai unsur hara diduga dapat memengaruhi tingkat kematangan polong buncis. Dosis yang rendah mengakibatkan kriteria panen polong dicapai pada interval waktu yang lama, sedangkan dosis tinggi mampu membuat polong mencapai kriteria panen pada interval yang lebih singkat.

Peran kompos lainnya adalah sebagai bahan pembenah tanah. Bahan organik yang terkandung pada kompos dapat dimanfaatkan sebagai sumber energi bagi mikroorganisme tanah. Dariah dkk. (2010) melaporkan bahwa pembenah tanah mampu meningkatkan produktivitas tanaman dan memerbaiki kualitas lahan kering masam, yang didominasi oleh fraksi liat. Penggunaan kompos sebagai bahan pembenah tanah dapat memerbaiki sifat-sifat tanah, sehingga penyerapan unsur hara dan air oleh tanaman tidak terhambat. 
Sehubungan dengan hal yang telah dijelaskan, percobaan ini bertujuan untuk mengetahui kombinasi antara dosis pupuk kompos dan interval panen yang terbaik bagi buncis tegak yang ditanam di Inceptisols Jatinangor.

\section{Bahan dan Metode}

Percobaan dilakukan di kebun percobaan Fakultas Pertanian Universitas Padjadjaran, di Ciparanje Kecamatan Jatinangor, Kabupaten Sumedang dengan ketinggian lokasi \pm 750 meter di atas permukaan laut (m dpl), pada Februari-April 2016.

Buncis yang digunakan adalah buncis tegak varietas Balitsa 1. Pupuk kompos yang digunakan adalah campuran dari serasah daun dan kotoran sapi dengan perbandingan 1:1, dosis yang digunakan adalah $0 \mathrm{~kg}, 2.5 \mathrm{~kg}, 5 \mathrm{~kg}$, dan $7.5 \mathrm{~kg}$. Pupuk dasar yang digunakan adalah urea, SP-36, dan $\mathrm{KCl}$. Pemberian pupuk kompos dilaksanakan sebelum penanaman tanpa proses inkubasi, sedangkan pupuk dasar diberikan pada umur tanaman 2 MST.

Keseluruhan perlakuan sebagai berikut :

$\mathrm{k}_{0} \mathrm{p}_{1}=0 \%$ kompos+interval 1 hari

$\mathrm{k}_{0} \mathrm{p}_{2}=0 \%$ kompos+interval 2 hari

$\mathrm{k}_{0} \mathrm{p}_{3}=0 \%$ kompos+interval 3 hari

$\mathrm{k}_{1} \mathrm{p}_{1}=50 \%$ kompos +interval 1 hari

$\mathrm{k}_{1} \mathrm{p}_{2}=50 \%$ kompos+interval 2 hari

$\mathrm{k}_{1} \mathrm{p}_{3}=50 \%$ kompos+interval 3 hari

$\mathrm{k}_{2} \mathrm{p}_{1}=100 \%$ kompos+interval 1 hari

$\mathrm{k}_{2} \mathrm{p}_{2}=100 \%$ kompos+interval 2 hari

$\mathrm{k}_{2} \mathrm{p}_{3}=100 \%$ kompos+interval 3 hari

$\mathrm{k}_{3} \mathrm{p}_{1}=150 \%$ kompos+interval 1 hari

$\mathrm{k}_{3} \mathrm{p}_{2}=150 \%$ kompos+interval 2 hari

$\mathrm{k}_{3} \mathrm{p}_{3}=150 \%$ kompos+interval 3 hari

Rancangan yang digunakan adalah Rancangan Acak Kelompok (RAK) terdiri dari 12 kombinasi antara dosis kompos $(0 \%, 50 \%$, $100 \%$, dan $150 \%$ ) dan interval panen (1 hari, 2 hari, dan 3 hari sekali). Perlakuan diulang sebanyak 3 kali. Petak percobaan berukuran $2 \times 2 \mathrm{~m}$ dengan jarak tanam $20 \mathrm{~cm} \times 40 \mathrm{~cm}$ dan terdiri dari 50 tanaman per petak.

Komponen pertumbuhan yang diamati terdiri dari tinggi tanaman diukur pada 2, 3, dan 4 MST. Indeks luas daun, bobot kering tanaman, dan nisbah pupus akar diukur pada vegetatif akhir atau ketika 5 MST. Komponen hasil dan kualitas hasil yang diamati terdiri dari persentase cabang produktif yang diukur pada generatif awal atau ketika 5 MST. Jumlah polong per tanaman, bobot polong per tanaman, bobot polong per petak, persentase polong layak pasar dan tidak layak pasar yang dihitung sebelum sortasi, serta panjang dan diameter polong, serta persentase jumlah kelas kualitas polong yang dihitung setelah sortasi. Angka yang berbeda nyata menurut uji F 5\% kemudian diuji lanjut dengan Uji Duncan.

\section{Hasil dan Pembahasan}

Komponen Pertumbuhan. Pemberian berbagai dosis kompos tidak berpengaruh terhadap komponen pertumbuhan tanaman buncis tegak. Tinggi tanaman pada umur 2, 3, dan 4 MST tidak menunjukkan signifikansi (Tabel 1).

Tabel 1. Rata-rata Tinggi Tanaman pada 2, 3, dan 4 MST (cm).

\begin{tabular}{cccc}
\hline \multirow{2}{*}{ Perlakuan } & \multicolumn{3}{c}{ Rata-rata Tinggi Tanaman $(\mathrm{cm})$} \\
\cline { 2 - 4 } & $2 \mathrm{MST}$ & $3 \mathrm{MST}$ & $4 \mathrm{MST}$ \\
\hline $\mathrm{k}_{0} \mathrm{p}_{1}$ & 6.97 & 9.56 & 18.96 \\
$\mathrm{k}_{0} \mathrm{p}_{2}$ & 6.89 & 10.03 & 18.36 \\
$\mathrm{k}_{0} \mathrm{p}_{3}$ & 7.29 & 10.65 & 19.02 \\
$\mathrm{k}_{1} \mathrm{p}_{1}$ & 7.2 & 11.05 & 22.01 \\
$\mathrm{k}_{1} \mathrm{p}_{2}$ & 7.02 & 10.49 & 21.16 \\
$\mathrm{k}_{1} \mathrm{p}_{3}$ & 6.56 & 9.53 & 20.67 \\
$\mathrm{k}_{2} \mathrm{p}_{1}$ & 7.77 & 11.88 & 20.88 \\
$\mathrm{k}_{2} \mathrm{p}_{2}$ & 7.47 & 11.26 & 21.69 \\
$\mathrm{k}_{2} \mathrm{p}_{3}$ & 7.22 & 10.71 & 17.67 \\
$\mathrm{k}_{3} \mathrm{p}_{1}$ & 7.43 & 10.49 & 21.05 \\
$\mathrm{k}_{3} \mathrm{p}_{2}$ & 7.3 & 11.31 & 20.07 \\
$\mathrm{k}_{3} \mathrm{p}_{3}$ & 7.25 & 11.55 & 21.43 \\
\hline \hline
\end{tabular}

Keterangan: Angka yang tidak diikuti huruf menunjukkan tidak berbeda nyata berdasarkan uji F pada taraf 5\%. MST: Minggu Setelah Tanam

Pupuk kompos yang digunakan memiliki kandungan $\mathrm{N}$ cukup tinggi, namun sifat kompos yang slow release menjadikan unsur hara tersedia secara lambat dan dalam jumlah yang sedikit (Setyorini dkk., 2006). Tingkat kematangan kompos yang kurang optimum dapat menjadikan fungsi pemberian kompos menjadi kurang efektif karena proses dekomposisi masih terus berlangsung.

Pemberian berbagai dosis kompos juga tidak berpengaruh terhadap komponen pertumbuhan lainnya seperti nilai Indeks Luas Daun (ILD), bobot kering tanaman, dan Nisbah Pupus Akar (NPA).

Rata-rata nilai ILD disajikan pada tabel 2. Lukito dkk (2010) mengungkapkan bahwa rendahnya nilai ILD dipengaruhi oleh intensitas penyinaran dan jarak tanam. Tanaman yang ditanam pada musim hujan cenderung memiliki nilai ILD yang lebih kecil. Hal ini dikarenakan oleh intensitas sinar matahari yang lebih sedikit. 
Tingginya curah hujan dan kematangan kompos yang kurang optimum menjadi penyebab dari tidak adanya perbedaan pada nilai ILD.

Tabel 2. Rata-rata Nilai Indeks Luas Daun pada 5 $\operatorname{MST}\left(\mathrm{cm}^{2}\right)$.

\begin{tabular}{cc}
\hline \hline Perlakuan & Rata-Rata Nilai ILD $\left(\mathrm{cm}^{2}\right)$ \\
\hline $\mathrm{k}_{0} \mathrm{p}_{1}$ & 0.18 \\
$\mathrm{k}_{0} \mathrm{p}_{2}$ & 0.18 \\
$\mathrm{k}_{0} \mathrm{p}_{3}$ & 0.25 \\
$\mathrm{k}_{1} \mathrm{p}_{1}$ & 0.34 \\
$\mathrm{k}_{1} \mathrm{p}_{2}$ & 0.25 \\
$\mathrm{k}_{1} \mathrm{p}_{3}$ & 0.22 \\
$\mathrm{k}_{2} \mathrm{p}_{1}$ & 0.25 \\
$\mathrm{k}_{2} \mathrm{p}_{2}$ & 0.19 \\
$\mathrm{k}_{2} \mathrm{p}_{3}$ & 0.16 \\
$\mathrm{k}_{3} \mathrm{p}_{1}$ & 0.29 \\
$\mathrm{k}_{3} \mathrm{p}_{2}$ & 0.24 \\
$\mathrm{k}_{3} \mathrm{p}_{3}$ & 0.30 \\
\hline \hline
\end{tabular}

Keterangan: Angka yang tidak diikuti huruf menunjukkan tidak berbeda nyata berdasarkan uji F pada taraf 5\%. MST: Minggu Setelah Tanam

Bobot kering tanaman (Tabel 3) dan nisbah pupus akar (Tabel 4) diukur ketika masa vegetatif akhir. Kedua komponen ini juga tidak berbeda nyata menurut uji $\mathrm{F}$ taraf $5 \%$. Penyebabnya adalah tingkat kematangan kompos yang kurang optimum, sehingga suplai unsur hara terhambat. Nilai NPA yang semakin tinggi mengindikasikan tanaman tumbuh pada kondisi yang menguntungkan (Harris, 1992). Perbedaan nilai NPA juga dipengaruhi oleh $\mathrm{C} / \mathrm{N}$ rasio kompos yang terbilang masih tinggi (20).

Tabel 3. Rata-rata Nilai Bobot Kering pada 5 MST (g).

\begin{tabular}{cc}
\hline \hline Perlakuan & Bobot Kering $(\mathrm{g})$ \\
\hline $\mathrm{k}_{0} \mathrm{p}_{1}$ & 4.16 \\
$\mathrm{k}_{0} \mathrm{p}_{2}$ & 4.23 \\
$\mathrm{k}_{0} \mathrm{p}_{3}$ & 5.78 \\
$\mathrm{k}_{1} \mathrm{p}_{1}$ & 7.53 \\
$\mathrm{k}_{1} \mathrm{p}_{2}$ & 5.95 \\
$\mathrm{k}_{1} \mathrm{p}_{3}$ & 5.54 \\
$\mathrm{k}_{2} \mathrm{p}_{1}$ & 5.70 \\
$\mathrm{k}_{2} \mathrm{p}_{2}$ & 4.81 \\
$\mathrm{k}_{2} \mathrm{p}_{3}$ & 4.13 \\
$\mathrm{k}_{3} \mathrm{p}_{1}$ & 6.55 \\
$\mathrm{k}_{3} \mathrm{p}_{2}$ & 5.81 \\
$\mathrm{k}_{3} \mathrm{p}_{3}$ & 6.85 \\
\hline \hline
\end{tabular}

Keterangan: angka yang tidak diikuti huruf menunjukkan tidak berbeda nyata berdasarkan uji F pada taraf 5\%. MST: Minggu Setelah Tanam

Komponen Hasil dan Kualitas Hasil. Pengamatan komponen hasil meliputi persentase cabang produktif, jumlah polong per tanaman, bobot polong per tanaman, dan bobot polong per petak. Pengamatan komponen kualitas hasil meliputi persentase jumlah polong layak pasar dan tidak layak pasar, panjang dan diameter polong, serta persentase jumlah kelas kualitas polong.

Tabel 4. Rata-rata Nilai Nisbah Pupus Akar pada 5 MST (NPA).

\begin{tabular}{cc}
\hline \hline Perlakuan & Nisbah Pupus Akar (NPA) \\
\hline $\mathrm{k}_{0} \mathrm{p}_{1}$ & 10.47 \\
$\mathrm{k}_{0} \mathrm{p}_{2}$ & 9.19 \\
$\mathrm{k}_{0} \mathrm{p}_{3}$ & 9.41 \\
$\mathrm{k}_{1} \mathrm{p}_{1}$ & 13.50 \\
$\mathrm{k}_{1} \mathrm{p}_{2}$ & 9.29 \\
$\mathrm{k}_{1} \mathrm{p}_{3}$ & 6.42 \\
$\mathrm{k}_{2} \mathrm{p}_{1}$ & 14.53 \\
$\mathrm{k}_{2} \mathrm{p}_{2}$ & 8.15 \\
$\mathrm{k}_{2} \mathrm{p}_{3}$ & 11.89 \\
$\mathrm{k}_{3} \mathrm{p}_{1}$ & 11.46 \\
$\mathrm{k}_{3} \mathrm{p}_{2}$ & 14.82 \\
$\mathrm{k}_{3} \mathrm{p}_{3}$ & 19.79 \\
\hline \hline
\end{tabular}

Keterangan: Angka yang tidak diikuti huruf menunjukkan tidak berbeda nyata berdasarkan uji F pada taraf 5\%. MST: Minggu Setelah Tanam

Tabel 5 menyajikan rata-rata persentase cabang produktif tanaman. Turuko dan Mohammed (2014) menyatakan bahwa unsur P berpengaruh terhadap pembentukan cabang produktif, namun proses dekomposisi kompos yang masih berlangsung turut berpengaruh pada ketersediaan unsur hara. Selain itu curah hujan yang tinggi mengakibatkan rendahnya intensitas cahaya matahari, sehingga pembentukan cabang produktif menjadi terhambat.

Tabel 5. Rata-rata Persentase Cabang Produktif pada 5 MST (\%).

\begin{tabular}{cc}
\hline \hline Perlakuan & Persentase Cabang Produktif $(\%)$ \\
\hline $\mathrm{k}_{0} \mathrm{p}_{1}$ & 43.96 \\
$\mathrm{k}_{0} \mathrm{p}_{2}$ & 37.08 \\
$\mathrm{k}_{0} \mathrm{p}_{3}$ & 44.72 \\
$\mathrm{k}_{1} \mathrm{p}_{1}$ & 45.64 \\
$\mathrm{k}_{1} \mathrm{p}_{2}$ & 41.51 \\
$\mathrm{k}_{1} \mathrm{p}_{3}$ & 41.90 \\
$\mathrm{k}_{2} \mathrm{p}_{1}$ & 41.94 \\
$\mathrm{k}_{2} \mathrm{p}_{2}$ & 45.24 \\
$\mathrm{k}_{2} \mathrm{p}_{3}$ & 42.84 \\
$\mathrm{k}_{3} \mathrm{p}_{1}$ & 38.42 \\
$\mathrm{k}_{3} \mathrm{p}_{2}$ & 38.28 \\
$\mathrm{k}_{3} \mathrm{p}_{3}$ & 42.71 \\
\hline \hline
\end{tabular}

Keterangan: Angka yang tidak diikuti huruf menunjukkan tidak berbeda nyata berdasarkan uji F pada taraf 5\%. MST: Minggu Setelah Tanam. 
Jumlah polong per tanaman, bobot polong per tanaman, dan bobot polong per petak disajikan pada Tabel 6. Jumlah dan bobot polong buncis masih jauh di bawah standar. Hal ini disebabkan oleh ketersediaan unsur hara yang terhambat.

Tabel 6. Rata-rata Jumlah Polong per Tanaman (buah), Bobot Polong per Tanaman (g), dan Bobot Polong per Petak (g).

\begin{tabular}{cccc}
\hline \hline Perlakuan & $\begin{array}{c}\text { Jumlah } \\
\text { Polong/ } \\
\text { Tan (buah) }\end{array}$ & $\begin{array}{c}\text { Bobot } \\
\text { Polong/ } \\
\text { Tan }(\mathrm{g})\end{array}$ & $\begin{array}{c}\text { Bobot } \\
\text { Polong/ } \\
\text { Petak (g) }\end{array}$ \\
\hline $\mathrm{k}_{0} \mathrm{p}_{1}$ & 16.22 & 52.83 & 3407.07 \\
$\mathrm{k}_{0} \mathrm{p}_{2}$ & 13.83 & 66.23 & 3460.67 \\
$\mathrm{k}_{0} \mathrm{p}_{3}$ & 14.44 & 58.71 & 3430.56 \\
$\mathrm{k}_{1} \mathrm{p}_{1}$ & 15.11 & 59.93 & 2842.79 \\
$\mathrm{k}_{1} \mathrm{p}_{2}$ & 20.06 & 76.38 & 2908.59 \\
$\mathrm{k}_{1} \mathrm{p}_{3}$ & 12.94 & 58.98 & 2839.00 \\
$\mathrm{k}_{2} \mathrm{p}_{1}$ & 25.61 & 98.94 & 2587.11 \\
$\mathrm{k}_{2} \mathrm{p}_{2}$ & 22.28 & 83.79 & 2526.51 \\
$\mathrm{k}_{2} \mathrm{p}_{3}$ & 12.56 & 56.01 & 2415.37 \\
$\mathrm{k}_{3} \mathrm{p}_{1}$ & 18.78 & 68.72 & 2980.47 \\
$\mathrm{k}_{3} \mathrm{p}_{2}$ & 16.17 & 58.69 & 2940.37 \\
$\mathrm{k}_{3} \mathrm{p}_{3}$ & 10.72 & 52.64 & 2916.16 \\
\hline \hline
\end{tabular}

Keterangan: Angka yang tidak diikuti huruf menunjukkan tidak berbeda nyata berdasarkan uji F pada taraf $5 \%$.

Berdasarkan pengamatan di lapangan, pemanenan polong dengan beberapa interval waktu mengakibatkan perbedaan bobot dan bentuk polong. Hal ini dikarenakan oleh polong yang dipanen dengan interval 2 dan 3 hari akan mendapatkan suplai fotosintat lebih banyak. Curah hujan yang tinggi diduga telah menggugurkan bunga dan menghambat pembungaan serta pembentukan polong buncis. Kebutuhan air tanaman buncis dari awal hingga panen adalah 288,5 mm (Tarigan, 2008).

Penghitungan persentase jumlah polong layak pasar dan tidak layak pasar dilakukan setelah kegiatan sortasi. Berdasarkan uji Duncan, kombinasi kompos 0\% dengan interval panen 1, 2, dan 3 hari, kompos $100 \%$ dan $150 \%$ dengan interval panen 1 hari memiliki pengaruh yang sama terhadap persentase layak pasar dan tidak layak pasar.

Tingginya persentase tidak layak pasar disebabkan oleh interval panen. Semakin lama polong dipanen, semkain tinggi kemungkunan untuk tidak layak pasar karena ukurannya semakin besar. Serangan hama dan penyakit pun turut menyumbang penyebab tingginya persentase tidak layak pasar. Penyebab paling jelas terlihat dari kelembaban yang tinggi, karena hal ini dapat menghambat pembentukan polong (Cahyono, 2003).

Tabel 7. Rata-rata Persentase Jumlah Polong Layak Pasar dan Polong Tidak Layak Pasar (\%).

\begin{tabular}{ccc}
\hline \hline Perlakuan & Polong LP $(\%)$ & Polong TLP $(\%)$ \\
\hline $\mathrm{k}_{0} \mathrm{p}_{1}$ & $46.62 \mathrm{abc}$ & $53.38 \mathrm{abc}$ \\
$\mathrm{k}_{0} \mathrm{p}_{2}$ & $60.16 \mathrm{a}$ & $39.84 \mathrm{c}$ \\
$\mathrm{k}_{0} \mathrm{p}_{3}$ & $51.33 \mathrm{abc}$ & $48.67 \mathrm{bc}$ \\
$\mathrm{k}_{1} \mathrm{p}_{1}$ & $39.29 \mathrm{bc}$ & $60.71 \mathrm{ab}$ \\
$\mathrm{k}_{1} \mathrm{p}_{2}$ & $42.89 \mathrm{bc}$ & $57.11 \mathrm{ab}$ \\
$\mathrm{k}_{1} \mathrm{p}_{3}$ & $35.71 \mathrm{bc}$ & $64.29 \mathrm{ab}$ \\
$\mathrm{k}_{2} \mathrm{p}_{1}$ & $49.38 \mathrm{abc}$ & $50.62 \mathrm{abc}$ \\
$\mathrm{k}_{2} \mathrm{p}_{2}$ & $38.11 \mathrm{bc}$ & $61.89 \mathrm{ab}$ \\
$\mathrm{k}_{2} \mathrm{p}_{3}$ & $40.14 \mathrm{bc}$ & $59.86 \mathrm{ab}$ \\
$\mathrm{k}_{3} \mathrm{p}_{1}$ & $48.53 \mathrm{abc}$ & $51.47 \mathrm{abc}$ \\
$\mathrm{k}_{3} \mathrm{p}_{2}$ & $42.32 \mathrm{bc}$ & $57.68 \mathrm{ab}$ \\
$\mathrm{k}_{3} \mathrm{p}_{3}$ & $34.09 \mathrm{c}$ & $65.91 \mathrm{a}$ \\
\hline \hline
\end{tabular}

Keterangan: Angka-angka yang diikuti huruf yang sama pada kolom yang sama tidak menunjukkan pengaruh yang tidak berbeda nyata menurut uji lanjut Duncan pada taraf $5 \%$.

Rata-rata panjang dan diameter polong disajikan pada Tabel 8. Pemberian berbagai dosis kompos dan interval panen tidak berpengaruh terhadap komponen tersebut. Hal ini dikarenakan oleh suplai unsur hara yang kurang, sebab pupuk organik mengandung unsur hara yang sedikit dan lambat tersedia (Tawakkal, 2009 dalam Nurmayulis dkk., 2014).

Tabel 8. Rata-rata Panjang Polong (cm) dan Diameter polong $(\mathrm{mm})$.

\begin{tabular}{ccc}
\hline \hline Perlakuan & $\begin{array}{c}\text { Panjang Polong } \\
(\mathrm{cm})\end{array}$ & $\begin{array}{c}\text { Diameter } \\
\text { Polong }(\mathrm{mm})\end{array}$ \\
\hline $\mathrm{k}_{0} \mathrm{p}_{1}$ & 11.88 & 6.54 \\
$\mathrm{k}_{0} \mathrm{p}_{2}$ & 11.58 & 6.66 \\
$\mathrm{k}_{0} \mathrm{p}_{3}$ & 12.09 & 6.23 \\
$\mathrm{k}_{1} \mathrm{p}_{1}$ & 11.09 & 6.14 \\
$\mathrm{k}_{1} \mathrm{p}_{2}$ & 12.10 & 6.55 \\
$\mathrm{k}_{1} \mathrm{p}_{3}$ & 12.82 & 6.81 \\
$\mathrm{k}_{2} \mathrm{p}_{1}$ & 10.79 & 6.89 \\
$\mathrm{k}_{2} \mathrm{p}_{2}$ & 12.06 & 6.72 \\
$\mathrm{k}_{2} \mathrm{p}_{3}$ & 12.00 & 6.61 \\
$\mathrm{k}_{3} \mathrm{p}_{1}$ & 11.38 & 6.30 \\
$\mathrm{k}_{3} \mathrm{p}_{2}$ & 11.48 & 6.46 \\
$\mathrm{k}_{3} \mathrm{p}_{3}$ & 11.97 & 6.93 \\
\hline \hline
\end{tabular}

Keterangan: Angka yang tidak diikuti huruf menunjukkan tidak berbeda nyata berdasarkan uji F pada taraf $5 \%$.

Kelembaban udara dan interval panen diduga berpengaruh terhadap pembentukan polong, sehingga bentuknya menjadi kurang sempurna. 
Persentase jumlah kelas kualitas polong yang tidak berbeda nyata disajikan pada Tabel 9 . Pertumbuhan yang terhambat karena banyak hal mengakibatkan polong kurang sesuai dengan kriteria. Perbedaan bentuk polong terlihat dari perbedaan interval waktu panen. Polong yang dipanen 3 hari sekali cenderung sudah membentuk biji, bila dibandingkan dengan pemanenan 1 hari.

Tabel 9. Rata-rata Persentase Jumlah Kelas Kualitas Polong A, B, dan C (\%)

\begin{tabular}{cccc}
\hline \hline Perlakuan & $\begin{array}{c}\text { Grade A } \\
(\%)\end{array}$ & $\begin{array}{c}\text { Grade B } \\
(\%)\end{array}$ & $\begin{array}{c}\text { Grade C } \\
(\%)\end{array}$ \\
\hline $\mathrm{k}_{0} \mathrm{p}_{1}$ & 6.11 & 34.63 & 59.26 \\
$\mathrm{k}_{0} \mathrm{p}_{2}$ & 7.23 & 41.00 & 51.77 \\
$\mathrm{k}_{0} \mathrm{p}_{3}$ & 8.87 & 50.24 & 40.89 \\
$\mathrm{k}_{1} \mathrm{p}_{1}$ & 11.04 & 38.96 & 50.00 \\
$\mathrm{k}_{1} \mathrm{p}_{2}$ & 5.46 & 30.94 & 63.60 \\
$\mathrm{k}_{1} \mathrm{p}_{3}$ & 4.67 & 26.44 & 68.89 \\
$\mathrm{k}_{2} \mathrm{p}_{1}$ & 8.53 & 34.84 & 56.64 \\
$\mathrm{k}_{2} \mathrm{p}_{2}$ & 5.85 & 33.15 & 61.00 \\
$\mathrm{k}_{2} \mathrm{p}_{3}$ & 4.33 & 24.56 & 71.11 \\
$\mathrm{k}_{3} \mathrm{p}_{1}$ & 7.70 & 36.37 & 55.92 \\
$\mathrm{k}_{3} \mathrm{p}_{2}$ & 7.63 & 43.23 & 49.14 \\
$\mathrm{k}_{3} \mathrm{p}_{3}$ & 9.00 & 51.00 & 40.00 \\
\hline
\end{tabular}

Keterangan: Angka yang tidak diikuti huruf menunjukkan tidak berbeda nyata berdasarkan uji F pada taraf $5 \%$

Penyebab dari tidak adanya perbedaan pada setiap kelas diduga karena ketersediaan unsur hara yang seidkit, akibat dari kurang optimumnya kematangan kompos. Selain itu penggunaan kotoran sapi sebagai bahan campuran kompos diduga masih memiliki kekurangan pada kandungan unsur hara. Tingkat kelembaban yang ekstrim untuk pertumbuhan buncis tegak juga menjadi penyebab rendahnya kualitas polong buncis yang dihasilkan.

\section{Kesimpulan dan Saran}

Kombinasi berbagai dosis pupuk kompos dengan interval panen tidak memberikan pengaruh terhadap pertumbuhan dan hasil, namun memberikan pengaruh terhadap kualitas hasil tanaman buncis tegak pada Inceptisols Jatinangor, yaitu persentase jumlah polong layak pasar dan polong tidak layak pasar.

Pemberian kompos dengan dosis $0 \%$ dan interval panen 1, 2, dan 3 hari, pemberian kompos dosis $100 \%$ dengan interval panen 1 hari, serta pemberian kompos dosis $150 \%$ dengan interval panen 1 hari, menunjukkan pengaruh terbaik terhadap kualitas hasil tanaman buncis pada Inceptisols Jatinangor, yaitu persentase jumlah polong layak pasar dan polong tidak layak pasar. Berdasarkan pertimbangan terhadap kegiatan konservasi tanah dan penekanan biaya produksi, maka pemberian kompos dosis $100 \%$ dengan interval panen 1 hari diambil sebagai kombinasi yang tepat bagi tanaman buncis tegak pada Inceptisols Jatinangor.

Saran. Perlu adanya penelitian lebih lanjut dengan bahan baku kompos dengan campuran kotoran hewan yang lain, selain campuran kotoran sapi. Hal ini dikarenakan setiap kotoran hewan memiliki kandungan unsur hara yang berbeda, sehingga dapat ditentukan kompos mana yang paling sesuai untuk pertumbuhan tanaman buncis. Kompos yang digunakan pun sebaiknya dipastikan tingkat kematangannya sudah optimum atau setidaknya diinkubasi terlebih dahulu sebelum penanaman.

Perlu dilakukan rekayasa lingkungan berupa pemberian naungan apabila akan membudidayakan buncis tegak di Jatinangor pada musim hujan. Tujuannya adalah untuk melindungi tanaman dari curah hujan yang terlalu tinggi, sehingga tidak akan mengganggu proses pembentukan polong dan menekan serangan penyakit

\section{Daftar Pustaka}

Alison, F. E. 1973. Soil Organic Matter and Its Role in Crop Production. Amsterdam. Elsevier Sci. Publishing Company. $631 \mathrm{hlm}$,

Badan Pusat Statistik. 2015. Tabel impor menurut komoditi tahun 2014. Available online at https://www.bps.go.id/all_new template.php. (diakses Desember 2015).

Cahyono, B. 2003. Kacang Buncis: Teknik Budidaya dan Analisis Usaha Tani. Yogyakarta. Penerbit Kanisius. $128 \mathrm{hlm}$.

Dariah, A., N. L. Nurida., dan Juabedah. 2010. Pemanfaatan pembenah tanah untuk pemulihan tanah terdegradasi yang didominasi fraksi pasir dan liat. Available online at http://balittanah.litbang.perta nian.go.id/. (diakses Januari 2016).

Direktorat Jenderal Hortikultura. 2014. Produksi tanaman sayuran di Indonesia tahun 20092013. Available online at http://horti. pertanian.go.id/node/253.(Diakses Desember 2015). 
Harris, R.W. 1992. Root-shoot ratios. Journal of Arboriculture 18(1): 39-42.

Lukito, A.M., Mulyono., Y. Tetty., H. Iswanto., dan N. Riawan. 2010. Buku Pintar Budi Daya Kakao. Jakarta. Agro Media Pustaka.

Murtilaksono, K dan S. Anwar. Potensi, Kendala, dan Strategi Pemanfaatan Lahan Kering dan Kering Masam untuk Pertanian (Padi, Jagung, Kedele), Peternakan, dan Perkebunan Menggunakan Teknologi Tepat Guna dan Spesifik Lokasi. Prosiding Seminar Nasional Lahan Suboptimal 2014, Palembang 26-27 September 2014.

Nurmayulis., A.A. Fatmawaty., dan D. Andini. 2014. Petumbuhan dan hasil tanaman buncis tegak (Phaseolus vulgaris L.) akibat pemberian pupuk kotoran hewan dan beberapa pupuk organik cair. Agrologia 3(2): 91-96.

Porch, T.G., J.S. Beaver., D.G. Debouck., S.A. Jackson., J.D. Kelly., and H. Dempewolf. 2013. Use of wild relatives and closely related species to adapt common bean to climate change. Agronomy 2:433-461.

Pujisiswanto, H dan D. Pangaribuan. 2008. Pengaruh Dosis Pupuk Kandang Sapi
Terhadap Pertumbuhan dan Produksi Buah Tomat. Prosiding Seminar Nasional Sains dan Teknologi-II. Universitas Lampung, 1718 November 2008.

Rajiman. 2015. Penerapan Teknologi di Lahan Sub Optimal. Available online at stppyogyakarta.ac.id. Diakses 11 Des. 2015.

Sarief, S. 1985. Kesuburan Tanah dan Pemupukan Tanah Pertanian. Bandung. CV. Pustaka Buana.168 hlm.

Setyorini, D*, R. Saraswati, dan E.K. Anwar. 2006. Pupuk Organik dan Pupuk Hayati: Kompos. Balai Besar Penelitian dan Pengembangan Sumberdaya Lahan Pertanian. Bogor. Hal 11-40.

Tarigan, S.D. 2008. Efektifitas embung untuk irigasi tanaman hortikultura di Cikakak Sukabumi. Jurnal Tanah dan Lingkungan 10(1): 1-6.

Turuko, M dan A. Mohammed. 2014. Effect of different phosphorus fertilizer rates on growth, dry matter yield and yield components of common bean (Phaseolus vulgaris L.). World Journal of Agricultural Research 2(3): 88-92. 